\title{
CLIPPERS: a recognizable image of a treatable disease
}

\section{CLIPPERS: uma imagem reconhecível de uma doença tratável}

Denise Fabri Rezende Engracia MELLO', Rodolfo Mendes QUEIROZ1', Cecilia MIYAKE'1, Soraia Ramos Cabette FÁBIO², Lucas Giansante ABUD'

An 80-year-old man with a history of stroke presented with eyelid ptosis of three years' duration. Magnetic resonance imaging (MRI) of the brain revealed findings (Figure 1) consistent with chronic lymphocytic inflammation with pontine perivascular enhancement responsive to steroids (CLIPPERS). As limitations precluded anatomopathological examination and the imaging pattern was characteristic enough to support treatment without biopsy, the decision was made to prescribe long-term corticosteroids. At the two-year follow-up, MRI findings had regressed (Figure 2) and the patient had improved clinically, meeting criteria for treatment response ${ }^{1}$. Biopsy is indicated when symptoms and MRI findings are unresponsive to treatment ${ }^{2}$. The differential diagnosis should include CNS lymphoma, neurosyphilis, and vasculitides ${ }^{3,4}$.

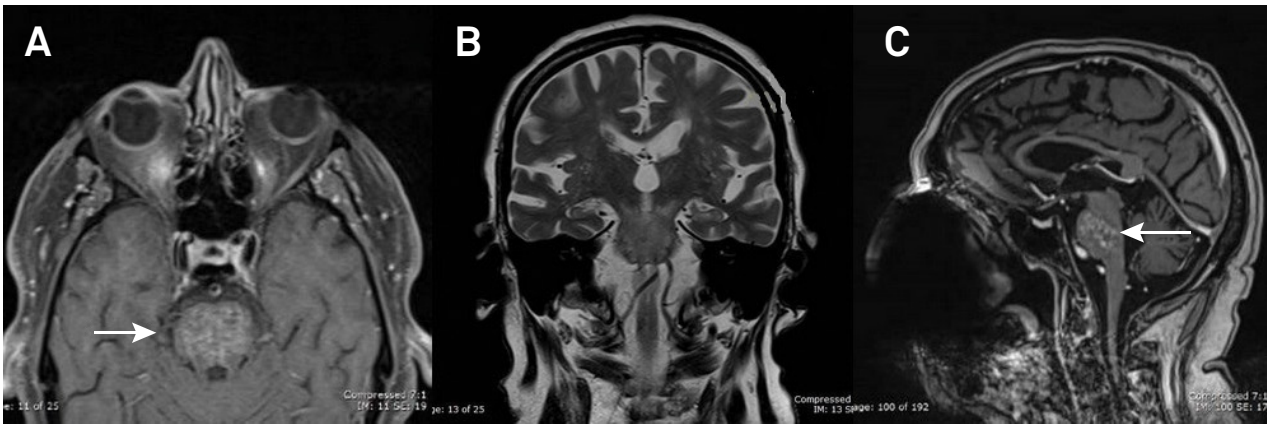

Figure 1. Contrast-enhanced brain MRI showing brainstem hyperintensity (white arrows) and disseminated perivascular areas of nodular enhancement, consistent with idiopathic inflammatory rhombencephalitis. There is evidence of cerebral and cerebellar volume reduction (Figure B).

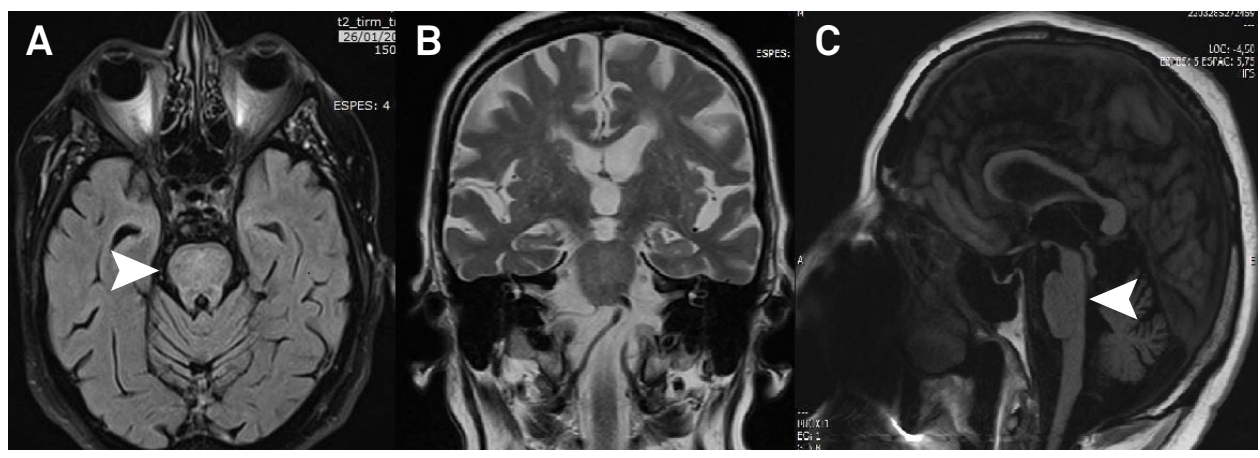

Figure 2. Contrast-enhanced brain MRI at the two-year follow-up. There is significant reduction of abnormal hyperintensity and contrast uptake in the brainstem (arrowhead) compared with the previous scan.

\footnotetext{
'MED Medicina Diagnóstica, Hospital São Lucas, Departamento de Radiologia e Diagnóstico por Imagem, Ribeirão Preto SP, Brasil; ${ }^{2}$ Hospital São Lucas, Departamento de Neurologia, Ribeirão Preto SP, Brasil

Denise Fabri Rezende Engracia Mello (iD) https://orcid.org/0000-0002-2967-5162; Rodolfo Mendes Queiroz (iD https://orcid.org/0000-0002-4893-4422 Cecilia Miyake (iD https://orcid.org/0000-0002-3167-2630; Soraia Ramos Cabette Fábio (iD https://orcid.org/0000-0001-8481-7146; Lucas Giansante Abud (iD) https://orcid.org/0000-0002-3777-5753

Correspondence: Denise Fabri Rezende Engracia Mello; Rua Prudente de Morais, 1170, Centro; 14015-100 Ribeirão Preto SP, Brasil;

E-mail: denisefabri8@gmail.com

Conflict of interest: There is no conflict of interest to declare.

Received 23 January 2019; Received in final form 19 July 2019; Accepted 27 July 2019.
} 
1. Taieb G, Wacongne A, Renard D, Figarella-Branger D, Castelnovo G, Labauge P. A new case of chronic lymphocytic inflammation with pontine perivascular enhancement responsive to steroids with initial normal magnetic resonance imaging. Brain; 2011.134(pt 8):182-183. https://doi.org/10.1093/brain/awq390

2. Taieb G, Allou T, Labauge P. Therapeutic approaches in CLIPPERS. Curr Treat Options Neurol. 2017 May;19(5):17. https://doi.org/10.1007/s11940-017-0455-4

3. Taieb G, Duflos C, Renard D, Audoin B, Kaphan E, Pelletier J, et al. Long-term outcomes of CLIPPERS (chronic lymphocytic inflammation with pontine perivascular enhancement responsive to steroids) in a consecutive series of 12 patients. Arch Neurol. 2012 Jul;69(7):847-55. https://doi.org/10.1001/archneurol.2012.122

4. Dudesek A, Rimmele F, Tesar S, Kolbaske S, Rommer PS, Benecke R, et al. CLIPPERS: chronic lymphocytic inflammation with pontine perivascular enhancement responsive to steroids: Review of an increasingly recognized entity within the spectrum of inflammatory central nervous system disorders. Clin Exp Immunol. 2014 Mar;175(3):385-96. https://doi.org/10.1111/cei.12204 